\title{
Miranda
}

Revue pluridisciplinaire du monde anglophone /

Multidisciplinary peer-reviewed journal on the English-

speaking world

$20 \mid 2020$

Staging American Nights

\section{Sleepless in Carver Country: Insomnia and Existential Crisis in Raymond Carver's Short Fiction}

\section{Marine Paquereau}

URL: http://journals.openedition.org/miranda/24786

DOI: 10.4000/miranda.24786

ISSN: 2108-6559

Publisher

Université Toulouse - Jean Jaurès

\section{Electronic reference}

Marine Paquereau, "Sleepless in Carver Country: Insomnia and Existential Crisis in Raymond Carver's Short Fiction", Miranda [Online], 20 | 2020, Online since 24 March 2020, connection on 16 February 2021. URL: http://journals.openedition.org/miranda/24786; DOI: https://doi.org/10.4000/miranda. 24786

This text was automatically generated on 16 February 2021.

\section{(c) $(1)$}

Miranda is licensed under a Creative Commons Attribution-NonCommercial-NoDerivatives 4.0 International License. 


\title{
Sleepless in Carver Country: Insomnia and Existential Crisis in Raymond Carver's Short Fiction
}

\author{
Marine Paquereau
}

1 In Carver country ${ }^{1}$, the night is not just a neutral backdrop used to create a reality effect. Carver's short stories taking place after dark are filled with heated arguments, bad dreams, and insomnia, suggesting that nighttime is a catalyst triggering moments of crisis in the lives of his characters specializing in "low-rent tragedies", as Maxine puts it in "One More Thing". Insomnia, in particular, concisely defined by the Merriam-Webster dictionary as "a prolonged and usually abnormal inability to get enough sleep", seems to become a means of expression for otherwise rather inarticulate characters.

2 For Ernest Fontana, "insomnia is a sickness" (447); for Kirk Nesset, it is "a common malady in Carver's ecosystem of malaise" (21). In his poem "Winter Insomnia", Carver himself wrote: "the mind is sick tonight" (Winter Insomnia 23), showing both the importance of insomnia in his literary universe and its close association with illness. In fact, though this somatic manifestation of the characters' psychological discomfort can have various origins, it always takes on an existential dimension: because they are unable to fall asleep, the characters are trapped in a moment of unwanted selfassessment whose nature will be defined in this paper. They find themselves in a state of inescapable consciousness which leads them to question the significance of their lives, and which threatens them with chaos and, ultimately, oblivion. I will show that insomnia, therefore, is a moment of critical wakefulness which challenges the characters' perception of their identity and makes them painfully aware of the tragedy of mortality. Interestingly, though insomnia is always an expression of the characters' awakening to the transience of human life and human relationships, its treatment in some stories from the latest collections seems to follow Carver's stylistic evolution as a writer, from pessimistic minimalism ${ }^{3}$ to a little less dire form of realism, in his 
collection Cathedral in particular, and might also be interpreted as the first step towards a form of acceptance, even of cure, of the characters' condition.

3 Sleepless characters appear in each of Carver's four main collections of short stories. In the first two collections, Will You Please Be Quiet, Please? and What We Talk about When We Talk about Love, the treatment of insomnia seems to follow a pattern based on gender. Thus two men, Arnold in "Are You A Doctor?" and Leo in "What Is It?" (both published in Will You Please Be Quiet, Please?), cannot sleep because they are anxiously waiting for their wives to come home. The stereotypical roles attached to each gender are reversed here, as two middle-aged men turn into modern Penelopes expecting the return, not exactly of the heroic warrior, but of the household's breadwinner. ${ }^{4}$

4 As the wife's absence is prolonged, so is the husband's wakefulness. Obviously, what is at stake here is not simply the frustration associated with the two men's wait and their forced passivity, but the hierarchy inside the couple. In both stories, the title is in the interrogative form, instilling doubt and questioning the characters' function right from the start. The first sentence of "Are You A Doctor?" describes Arnold in the outfit of the perfect "househusband": "In slippers, pajamas, and robe, he hurried out of the study when the telephone began to ring" (31). On the contrary, his wife is immediately presented as an active businesswoman: "She called-late like this, after a few drinkseach night when she was out of town. She was a buyer, and all this week she had been away on business" (31). Of course the dashes are here to underline the most important pieces of information, two elements that seem disturbing enough to be mentioned in an otherwise very factual sentence: it is late and she might be drunk. Arnold's powerlessness in this situation is visible, ironically, in the fact that he is nowhere to be seen in the passage: his wife does not even call him, she just "calls". The personal pronoun is not mentioned, perhaps because it is, just like the man it refers to, taken for granted.

5 Arnold tries to regain a sense of power and virility by leaving home and meeting another woman during his sleepless night. But the clumsy and short-lived affair does not allow him to assert his identity, quite the opposite: "Appalled at himself, knowing he would despise himself for it, he stood and put his arms clumsily around her waist" (39). The repetition of the reflexive pronoun "himself" highlights the fact that Arnold is undergoing a form of dissociation and cannot really come to terms with the situation nor with his own image. When Arnold's wife finally calls him, she unknowingly points to his alienation: “'Are you there, Arnold?' she said. 'You don't sound like yourself" (40, emphasis mine). The story ends with this remark, leaving the reader and the characters themselves to ponder on Arnold's identity (or lack thereof).

6 In "What Is It?" Leo's wife Toni is also the one in charge, since she does all the work to sell their convertible before it is seized by the court. After all, she knows best: we learn at the beginning of the story that Toni and Leo met when she successfully sold him a children's encyclopedia although he was childless at the time. She is also the one who decides when to call and when to hang up while she is away trying to sell their car, whereas all Leo can do is ask her questions which remain unanswered, or only receive vague replies: "'Where are you?' he says. He hears piano music, and his heart moves. 'I don't know, she says. Someplace"' (213).

7 Leo and Toni have been deceived by the excesses of consumer society, which led them to bankruptcy. Before they lost everything, they tried to have a full life, as the enumeration of their expenses suggests: 
Food, that was one of the big items. They gorged on food. He figures thousands on luxury items alone. Toni would go to the grocery and put everything she saw. [..] She joins all the book clubs. [...]. They enroll in the record clubs for something to play on the new stereo. They sign up for it all." (212)

But in a world in which you exist only if you own something, in which moral values are disregarded ${ }^{5}$, being bankrupt, i.e. being forced to renounce the American Dream of materialistic achievement, is fatal ${ }^{6}$. That may partly explain why Toni is much more severe than Arnold's wife when it comes to assigning her husband an identity, and condemns Leo to complete annihilation: "But you don't have money [...]. And your credit's lousy. You're nothing" (209, emphasis in the text). Although he tries to assert himself during his sleepless night, Leo's exclamation "I'm right here!" (216), which bears an ontological resonance, is immediately followed by a blank space, showing that his insignificant existence is not acknowledged by anybody.

Contrary to their male counterparts, the insomniac women who appear in the first two collections and who, interestingly enough, are both named Nancy, don't have to worry about their partners' whereabouts. But although they are in the physical presence of their husbands, they feel deserted. In fact, "The Student's Wife" (Will You Please Be Quiet, Please?) and "I Could See The Smallest Things" (What We Talk about When We Talk about Love) play on the oscillation between the women's feeling of abandonment, due to their inability to communicate with their sleeping partners, and their wish for another form of abandonment, "the peaceful abandonment" (translation mine) mentioned by Nicolas Surlapierre in Montandon's Dictionnaire littéraire de la nuit, that is to say the oblivion offered by sleep.

In "The Student's Wife", Nancy is but "an appendage of her husband's inadequacies" (Saltzman 50), as the possessive form in the title underlines. In order to please him she has to limit herself to the role of the audience, the passive listener to whom he proudly reads poems. Although she does fall asleep at the beginning of the story while listening to her husband Mike's "confident sonorous voice" (Will You Please Be Quiet, Please? 122), she wakes up after "a funny little dream" (123), and then never manages to go back to sleep. In the dream, she has to "sacrifice and sit all cooped up in the back" (124) of a motorboat after an argument with her husband. As Fontana explains, "[t]he dream is obviously, perhaps too obviously, a metaphor for Nan's discomfort in her marriage" (448), for her always having to humor her husband while being perpetually pushed into the background.

11 During her insomnia, she tries to find solace in conversations with Mike, because she “[doesn't] want to be awake by [herself]" (Will You Please Be Quiet, Please? 126), but he remains selfishly indifferent to her predicament, saying "I wish you'd leave me alone, Nan" (128), before turning his back to her and going back to sleep. The "growing pains" (126) that she complains about during her sleepless night can then be seen as the somatic expression of her growing anxiety as she reflects on their mediocre life. ${ }^{8}$ Thus, she makes a list of the things she appreciates, which soon turns into a list of things she wishes she had, thanks to a shift from "I like" to "I'd like":

I like good foods, steaks and hash-brown potatoes, things like that. I like good books and magazines, riding on trains at night, and those times I flew in an airplane. [...] I like Janice Hendricks very much. I'd like to go dancing at least once a week. I'd like to have nice clothes all the time. [...] And I'd like us to have a place of our own. [...] I'd like us both just to live a good honest life without having to worry about money and bills and things like that. (Will You Please Be Quiet, Please? 127-128) 

not to own, a common trait in Carver's short stories, in which most characters are in dire straits.

When she eventually decides to get up, Nancy is surrounded with threatening signs that add to her anxiety because she cannot fully comprehend them. For Günter Leypoldt, this is a case of "arrested epiphany", which he describes as "a distinct disparity between the character's feeling of revelation and his or her lack of understanding of what sort of insight the revelation is supposed to provide" (535). For instance, she does not have the necessary tools to grasp the meaning of the "terrible" sunrise she sees: "Not in pictures she had seen nor in any book she had read had she learned a sunrise was so terrible as this" (Will You Please Be Quiet, Please? 131). Contrary to traditional interpretations, dawn doesn't bring hope in Nancy's world. Worse, the very last paragraph describes Nancy's sleeping husband as a corpse enveloped in his white shroud: "He looked desperate in his heavy sleep, his arm flung out across her side of the bed, his jaws clenched. As she looked, the room grew very light and the pale sheets whitened grossly before her eyes" (131). This image is hardly surprising, as Montandon's literary dictionary of the night reminds us that a sleeping body and a dead body have the same posture ${ }^{9}(1309)$, but it aptly reflects Nancy's existential crisis and her sudden awareness of her own mortality. Her last resort is God, and the story ends with a desperate prayer: 'God,' she said. 'God, will you help us, God?' she said" (Will You Please Be Quiet, Please? 131). However, her plea remains unanswered, and the silence that follows, illustrated by the blank space at the bottom of the page, is deafening.

The second story featuring a sleepless female protagonist, "I Could See The Smallest Things", is told in the first-person, which suggests that the character, who speaks for herself, is more articulate than the student's wife. She seems to have a better grasp of the situation; thus in the first paragraph, she explains that she won't be deceived by hackneyed nighttime symbols: "A big moon was laid over the mountains that went around the city. It was a white moon and covered with scars. Any damn fool could see a face in it" (What We Talk about When We Talk about Love 26, emphasis mine). But although this Méliès-like moon is denounced as a cliché, it can still be interpreted as an anthropomorphic projection of the character's feelings, the scars being the metaphorical illustration of her psychological pain.

In fact, the two insomniac women share more than a first name. Just like "Nan" in "The Student's Wife", "Nancy" lives in a stifling environment, as illustrated by the insistence on the "fences" separating her yard from the neighbor's $(27,28)$ and on the gate she should close ("I was in bed when I heard the gate" [26]; "It was then that I remembered I'd forgotten to latch the gate" [30]). Moreover, she experiences just the same unease as Nan when she looks at her husband. Though all is calm, her husband Clifford does not seem to be sleeping in heavenly peace: "Cliff's breathing was awful to listen to" (26). His complexion and his position ("his arms hugged his pale chest" [26]) make him look like a recumbent statue, which contributes to the creation of an atmosphere of impending death.

Again, insomnia turns into a moment of forced introspection for the main character, and acts as a reminder of the transient nature of life. This is made obvious thanks to the slug imagery used throughout the story. When Nancy decides to "go out and fasten up the gate" (27), she meets her neighbor Sam, who used to be friends with Clifford 
before a drunken fight. Sam shows her "some wormy things curled on a patch of dirt" (28) that he is trying to exterminate. They turn out to be slugs, but the defamiliarization brought about by the use of the vague term "things" delaying their identification adds to the uncanny atmosphere, which is also created by Nancy's reflection on her unusual outfit ("It felt funny walking around outside in my nightgown and my robe" [27]) and above all by the moonlight: "There was light enough so that I could see everything in the yard" (26); "Everything lay in moonlight, and I could see the smallest things" (26); "The moon lighted up everything" (27). With this description of the moon as a spotlight, the whole scene seems eerily staged. The characters' existence itself therefore appears unreal, and even on the verge of disintegrating into nothingness, like the slugs Sam has put Ajax powder on. Significantly, right after this passage, Nancy spots a plane above their heads: "A plane passed overhead. I imagined the people on it sitting belted in their seats, some of them reading, some of them staring down at the ground" (29). By adopting the passengers' perspective, she implicitly places herself in the position of a tiny slug, and acknowledges her own insignificance.

Back in her bedroom, Nancy still cannot fall asleep, nor can she get rid of the image of the agonizing slugs:

I opened my eyes and lay there. I gave Clifford a little shake. He cleared his throat.

He swallowed. Something caught and dribbled in his chest.

I don't know, it made me think of those things that Sam Lawton was dumping powder on. (30)

Again, Nancy's unsuspecting husband acts as the receptacle for her fear of death. The story ends on the expression of her growing anxiety: "I thought for a minute of the world outside my house, and then I didn't have any more thoughts except the thought that I had to hurry up and sleep" (30). "Her only thought is the oblivion of thoughtlessness" (96), Adam Meyer explains. Nancy wishes for the blessing of being unaware of one's inescapable solitude and eventual obliteration, but sleep is a form of escapism that is denied to her.

Contrary to most other insomniacs in Carver's fiction, Iris and Jack, the couple in "Whoever Was Using This Bed" (Elephant), are awake together, and they do speak to each other during their sleepless night, caused by a random phone call. Fontana comments on the interesting use of the present tense in the story:

Instead of remembering insomnia, the narrator is experiencing insomnia as he narrates the text; the alertness to the details of the moment that characterize the insomniac's experience becomes the mode of narrative presentation. (449)

It conveys a sense of immediacy by giving us the impression that the story is unfolding right before our eyes, but it also places us in the uncomfortable position of the intruders prying into the characters' private life, eavesdropping on their conversation. In fact, in this short story Carver plays with our expectations by distorting the potentially romantic clichés attached to bedroom scenes and pillow talks.

21 Thus, the use of the indefinite pronoun "whoever" in the title, which questions the identity of the bed's owner, as well as the narrator's insistence on the messy state of the bed ${ }^{10}$ hint at a certain lack of intimacy and point to possible conjugal problems. Jack even seems to resent his wife's invasive presence: "she's more on my side than her own side" (Elephant 28-29); "Why don't you move over a little and give me some of those covers?" (28). The bed becomes the stage for an intimate power struggle suggesting 
that it is in fact their couple, more than the covers, which might need some reorganization.

The question of the ties that bind the characters is all the more meaningful since their insomnia is dominated by the notion of disconnection. As Fontana puts it, the short story as a whole "is built around the metaphor of 'unplugging"' (451). The call that wakes them up at three a.m., is the result of Jack's forgetting to unplug the phone, a daily routine established after he separated-disconnected-from his first wife:

After Iris and I started living together, my former wife, or else one of my kids, used to call up when we were asleep and want to harangue us. They kept doing it even after Iris and I were married. So we started unplugging our phone before we went to bed. (Elephant 28)

In Jack's speech, cutting off the phone symbolically amounts to severing all links with his former family. But this time, at the other end of the line is another sleepless, possibly intoxicated, woman insistently asking to talk to someone named "Bud" ("Is Bud there?' this woman says, very drunk" [27]), or maybe simply to a friendly ear, as suggested by the connotation of the name "Bud", which may be short for "buddy". In that sense, the anonymous woman sounds very much like a "Nancy": like the protagonists of "The Student's Wife" and "I Could See The Smallest Things", she appears to be a lonely woman adrift in a senseless world, as shown by her unanswered questions: "Is Bud there?" (27); “Bud?' the woman says. 'What are you doing, Bud?" (27). As Arthur Bethea explains, "[ $t$ ]he phone calls-three of them, the first occurring at three a.m.-are early hints that Carver's story takes place in a universe without transcendence. The Holy Trinity has no sway here; thus the substitution of three vain, exclamatory references to a higher power around three in the morning" (164). There is no understanding nor salvation to be found in religion, in a world where God is seemingly absent. Nor is there any sense of community, any display of solidarity. In fact Iris and Jack have no sympathy for the poor woman, and Jack even ends up being rather threatening after her third, apologetic call: "Please don't ever call here again. Just don't, OK? Do you hear me? If you're not careful, I'll wring your neck for you" (Elephant 44, emphasis mine). Again the specter of death looms in the darkness of the Carverian night.

The story itself begins and ends with metaphorical references to death, the very first sentence of the story ("The call comes in the middle of the night, three in the morning, and it nearly scares us to death" [27]) echoing the very last one ("The line goes dead, and I can't hear anything" [44]) in a cyclic rhythm expressing the inevitability of death. Therefore, it is not surprising that the couple's central conversation (a rather unexpected type of pillow talk, as mentioned earlier) should revolve around the concept of euthanasia, more precisely the idea of unplugging-disconnecting-not simply a phone, but a life-support machine:

mostly they were talking about this nurse who unplugged six or eight people from their machines. At this point they don't know exactly how many she unplugged. She started off by unplugging her mother, and then she went on from there. It was like a spree, I guess. She said she thought she was doing everybody a favor. She said she hoped somebody'd do it for her, if they cared about her. (37, emphasis in the text)

The conversation about the murderous nurse who literally severed all links with her mother and about various other people who resorted to euthanasia ${ }^{11}$ then takes a more personal turn which, again, reveals dissonance inside the couple. While Iris considers 
euthanasia a merciful gesture and asks her husband to let her go if need be ("I want you to promise me you'll pull the plug on me, if and when it's ever necessary" [40]), Jack is much less assertive:
All right, if it's what you want to hear, I'll pull the plug for you. If that's what you want me to do, I'll do it. If it will make you happy, here and now, to hear me say so, I'll say it. I'll do it for you. I'll pull the plug, or have it pulled, if I ever think it's necessary. But what I said about my plug still stands. Now I don't want to have to think about this stuff ever again. I don't even want to have to talk about it again. I think we've said all there is to say on the subject. We've exhausted every angle. I'm exhausted. (43, emphasis in the text)

The accumulation of "if" clauses in this passage highlights Jack's doubt regarding the appropriateness of such an act. The play on the polysemy of "exhausted" also underlines his mental fatigue as he tries to come to terms with his wife's demand and, probably, with his own choice: “No. Don't unplug me. I don't want to be unplugged. Leave me hooked up just as long as possible" (41). Jack does not want to be put to sleep; insomnia, therefore, though undesirable at first, ironically allows him to maintain a precarious link with the rest of humanity. He wishes to keep a form of connection, which is denied to him in the final scene:

But while I'm trying to tell all this to the woman, while I'm trying to make myself understood, my wife moves quickly and bends over, and that's it. The line goes dead, and I can't hear anything. (44)

By finally unplugging the phone, his wife condemns him to utter silence, and, symbolically, to death. The exhaustion mentioned by the narrator, then, is both ontological and linguistic, and can therefore be seen as a comment on Carver's style, which relies on indefinite forms, omissions and silences.

Like "Whoever Was Using This Bed", the short story "Menudo" is first based on the discomfort inspired by disorder. This time, however, the chaotic lives of the characters is not symbolized by an unmade bed but by heaps of leaves that need to be raked:

A couple of days ago, when I couldn't sit still, I raked our yard-Vicky's and mine.

[...] I had an urge then to cross the street and rake over there, but I didn't follow

through. It's my fault things are the way they are across the street". (Elephant 55)

Contrary to Nancy in "The Student's Wife", for instance, the narrator knows very well why he cannot sleep despite being "exhausted"12 and having "taken nearly all of Vicky's pills" (55): "across the street" lives his mistress Amanda, and he laments over the repercussions of their affair on their respective couples: "Is this what it all comes down to then? A middle-aged man involved with his neighbor's wife, linked to an angry ultimatum? What kind of destiny is that?" (69). In fact, the narrator seems to believe that raking his neighbors' lawn will assuage his guilt and change his destiny by reintroducing order in his existence.

Still unable to sleep, he recounts several memories, and especially the "menudo" his friend Alfredo offered to cook for him at a time when he "wasn't in his right mind" (66): "he said he was going to fix menudo for me. He said it would be good for what ailed me" (67). The fact that his friend Alfredo should choose the verb "to fix" is significant, because it suggests that something-namely the narrator' tumultuous lifeis broken and needs to be repaired, But as Ewing Campbell explains,

When he wakes up late the next day, the people and the menudo are gone. He has missed out on the menudo. 
It seems an insignificant thing to remember, but the facts of his life can be reduced to this one event. He has missed out. Avoiding strange, uncomfortable, and painful realities through alcohol, extramarital relations, and denial, he never experiences life in ways that might help him develop. (76)

31 The narrator's behavior betrays his escapist tendencies, which lead to constant wandering, or what he himself calls "[c]ompulsion and error, just like everybody else"13 (Elephant 61). Still, insomnia, in his case, might turn into a form of remedy. As Fontana remarks, the narrator clearly considers "sleep is a form of death" (450), hence his refusal to go to sleep when he stayed by his dying father's side a few years ago, as if death were somehow contagious: "I never took my clothes off and didn't go to bed. I may have catnapped in a waiting-room chair from time to time, but I never went to bed and slept" (Elephant 59, emphasis in the text). In that sense, he is not different from the other Carverian insomniacs. ${ }^{14}$ But this time, the character's sleeplessness, his "resistance to death" (Fontana 450), might also be a first step towards actively reorganizing his life. Thanks to his insomnia, he seems to have an epiphanic moment, and he is finally able to take matters-in the shape of a rake-into his own hands: "I go outside to the garage and find the rake and some lawn bags. By the time I get around to the front of the house with the rake, ready to begin, I feel I don't have the choice in the matter any longer" (Elephant 69). His final impulse seems gratifying enough ("I'm happy, raking" [69]) for the reader to interpret the open ending as a positive evolution: "I look both ways and then cross the street" (71). The verbs of action indicate he has summoned the courage to do what he had failed to do at the beginning ("I had an urge then to cross the street and rake over there, but I didn't follow through" [55]). Of course, in Carver's fiction, optimism is scarce and never fully explicit, and consequently the nature of the narrator's resolution is unclear. In fact, the story ends on the same "darkly distinctive late Carverian optimism" (Nesset 80-81) as when the narrator wonders whether he will ever get to eat menudo a few paragraphs earlier: "I'll probably die without ever tasting menudo. But who can say?" (Elephant 69). The interrogative form shows that in Carver country, happiness is a precarious hope, a possibility rather than a certainty.

In "A Small, Good Thing", the characters' sleeplessness has a very tangible cause: two worried parents, Ann and Howard Weiss, are in a hospital room watching over their son Scotty, who was the victim of a hit and run on his birthday. Here their vigil is in stark contrast to Scotty's coma, which the doctor insists on calling a "very deep sleep" 15 (Cathedral 62). Again, sleep is associated with death, in a very literal way since Scotty eventually expires without really waking up from his coma. At the end of the story, the disconsolate parents confront the baker who kept harassing them on the phone over Scotty's forgotten birthday cake. But their anger gives way to the restoration of a sense of community when the baker begs for their forgiveness and offers them bread and cakes, because "[e]ating is a small, good thing in a time like this" (83). Ann is "suddenly hungry" (83), which indicates a symbolic rebirth. The baker confides in the parents to explain his curt behavior:

They nodded when the baker began to speak of loneliness, and of the sense of doubt and limitation that had come to him in his middle years. He told them what it was like to be childless all these years. To repeat the days with the ovens endlessly full and endlessly empty. (83)

The repetition of the privative suffix-less, which echoes the word "loneliness", highlights the baker's disconnection from the rest of the world. Critics have often 
insisted on the religious connotations of the story, especially when the baker, in a Christ-like position, breaks the bread open: '“Smell this,' the baker said, breaking open a dark loaf. 'It's a heavy bread, but rich"' (84). But instead of God, the parents find solace in the warmth of a blunt and down-to-earthman. "A Small, Good Thing" is a secular story of reciprocal salvation: at the end of a long, sleepless night, the characters are redeemed when they manage to love their neighbors as themselves.

Though the characters' insomnia can have an external cause, it is always the physical expression of their inner turmoil, leading to moments of forced self-examination and dark epiphanies (more or less eye-opening, depending on the insight of the characters). In Carver's short fiction, sleepless characters realize that they are essentially alone in a God-forsaken world, and slowly come to understand that human existence itself may well be the real nightmare.

Insomnia is metonymically associated with death, first because it triggers the symbolic death of alienated characters, especially male ones, and then because insomniacs, though they envy their partners' escapist abandonment to sleep, also interpret sleep as a form of memento mori.

They are prisoners of a form of ontological exhaustion which echoes Carver's seemingly neutral writing, based on empty forms and implicit details, that is to say devices that seem to epitomize the exhaustion of language itself.

Still, as Carver's style evolves towards more hopeful considerations, so does his treatment of insomnia. By becoming both the symptom and the cure of some characters' disconnection, it introduces a touch of potential, low-key optimism. The "terrible sunrise" of "The Student's Wife" then gives way to the more promising dawn of "A Small, Good Thing", this "high, pale cast of light in the windows" (84) which brings together, even for a brief moment, a solitary baker and two grieving parents, and proves that, sometimes, the sun also rises in Carver country, though unostentatiously.

\section{BIBLIOGRAPHY}

Bethea, Arthur F. Technique and Sensibility in the Fiction and Poetry of Raymond Carver. New York: Routledge, 2001.

Campbell, Ewing. Raymond Carver, A Study of the Short Fiction. New York: Twayne, 1992.

Carver, Raymond. Winter Insomnia. Santa Cruz: Kayak, 1970.

---. Will You Please Be Quiet, Please? 1976. New York: Vintage, 1992.

---. What We Talk about When We Talk about Love. 1981. London: Vintage, 2003.

---. Cathedral. 1983. London: Vintage, 2003.

---. Elephant and Other Stories. 1988. London: Vintage, 2003. 
---. Carver Country: The World of Raymond Carver. With photographs by Bob Adelman. New York: Scribner, 1990.

Fontana, Ernest. “Insomnia in Raymond Carver's Fiction.” Studies in Short Fiction 26.4 (Fall 1989): 447-451.

Gentry, Marshall B., and William L. Stull (eds.). Conversations with Raymond Carver. Jackson: UP of Mississippi, 1990.

Leypoldt, Günter. “Raymond Carver's 'Epiphanic Moments'.” Style 35.3 (Fall 2001): 531-547.

Meyer, Adam. Raymond Carver. New York: Twayne, 1995.

Montandon, Alain (ed.). Dictionnaire littéraire de la nuit. Paris: H. Champion, 2013.

Nesset, Kirk. The Stories of Raymond Carver, A Critical Study. Athens: Ohio UP, 1995.

\section{NOTES}

1. Carver Country is the title of a book made up of texts by Raymond Carver and photographs by Bob Adelman published in 1990.

2. In the short story "One More Thing", Maxine, the main character, is trying to get rid of her alcoholic and abusive husband. When she learns that her teenage daughter has stopped going to school, she describes the situation as "another tragedy in a long line of low-rent tragedies" (What We Talk about When We Talk about Love 130).

3. Carver never really appreciated this label describing the pared-down style of his stories, more specifically those of the collection What We Talk about When We Talk about Love: "There's something about 'minimalist' that smacks of smallness of vision and execution that I don't like" (Gentry and Stull xii-xiii).

4. The vision of the passive, powerless man acting as a contemporary Penelope is a recurrent motif in Carver's fiction: in "After the Denim" another sleepless man, James Packer, decides to "[take] up his basket of embroidery" (What We talk about When We Talk about Love 66) to try and forget about his wife's potentially mortal disease.

5. The man who buys their car explains "he'd rather be classified a robber or a rapist than a bankrupt" (215). Here, bankruptcy is metonymically associated with two different types of crime and therefore seen as a crime itself, a very serious one at that.

6. Leo even contemplates suicide during his sleepless night: "He [...] considers whether he should go to the basement, stand on the utility sink, and hang himself with his belt" (213).

7. 'Pontalis, dans un court texte 'Dormeuse', regrette de ne pas être assez poète pour faire l'éloge du sommeil ou de la dormeuse, 'celle qui s'abandonne au sommeil dans un lit après l'amour, dans un pré après la moisson. Cet abandon tranquille viendrait-il de la certitude qu'elle ne sera jamais abandonnée?" (Montandon 1309).

8. Studying the dialogue (or lack thereof) between Nancy and her husband, Fontana asserts that "in fact, her insomnia is the experience of feeling herself 'growing,' growing in awareness," while her husband keeps refusing to "share in her fear and terror" (Fontana 448).

9. “il est aussi ardu de dire 'je dors' que 'je suis mort' [...] parce que les deux semblent posturalement proches" (Montandon 1309).

10. "The covers are up around her shoulders. The blankets and the sheet have been pulled out from the front of the bed. If we want to go back to sleep-I want to go back to sleep, anyway-we may have to start from scratch and do this bed over again." (Elephant 28); "But the covers don't feel right. I don't have any sheet; all I have is blanket. [...] We should make up the bed again" (28); "The covers are turned every which way, and it's five o'clock in the morning" (34); "We're 
sitting on the part of the bed where we keep our feet when we sleep. It looks like whoever was using this bed left in a hurry. I know I won't ever look at this bed again without remembering it like this" (40).

11. At first, their discussion on euthanasia is based on newspaper headlines: "Did you see in the paper where that guy took a shotgun into an intensive-care unit and made the nurses take his father off the life-support machines?" (37); "What about that quadriplegic woman on the news who says she wants to die, wants to starve herself to death? [...] it said in the paper that she's begging them to unplug her" (37-38, emphasis in the text).

12. The polysemous notion of exhaustion (be it physical, psychological or linguistic) appears again in this short story, where it seems to act as the necessary condition for the narrator to finally experience some form of epiphany and take action, as we shall see below.

13. Compulsive behaviors are indeed common in Carver's fiction, especially among male characters who engage in pointless and complicated affairs, like the protagonists in "Vitamins" or "Jerry and Molly and Sam".

14. Conversely, when he hears about his wife Vicky's own affair, he takes to his bed and sleeps, as he were sentenced to a symbolic death after being replaced by another man: "And then a year or so ago I found out Vicky was seeing somebody else. Instead of confronting her, I went to bed when I heard about it, and stayed there. I didn't get up for days, a week maybe-I don't know. [...] I couldn't get enough sleep" (59).

15. “'No, I don't want to call it a coma,' the doctor said and glanced over at the boy once more. 'He's just in a very deep sleep. It's a restorative measure the body is taking on its own'” (62).

\section{ABSTRACTS}

In Raymond Carver's short fiction, the night is not simply used as a realistic backdrop. In his short stories taking place after dark, Carver distorts the clichés generally associated with the comfortable intimacy of a night spent in the conjugal bed. On the contrary, his characters suffering from insomnia are condemned to complete isolation and are painfully reminded of their own mortality. This article, therefore, examines how the motif of the sleepless night is used metaphorically to express the anxiety of otherwise rather inarticulate characters, who want their share of the American Dream but feel trapped in an existential nightmare.

Chez Raymond Carver, la nuit n'est jamais uniquement une toile de fond réaliste. Dans ses nouvelles se déroulant après la tombée de la nuit, Carver joue à déconstruire les clichés généralement associés au confort de l'intimité nocturne et du lit conjugal. L'insomnie qui frappe certains de ses personnages les renvoie au contraire à leur complète solitude et à leur condition de mortels. Cet article cherche donc à voir comment la nuit blanche carvérienne est utilisée métaphoriquement pour exprimer l'angoisse de personnages souvent peu expansifs, qui veulent leur part du Rêve américain mais se retrouvent pris au piège d'un cauchemar existentiel.

\section{INDEX}

Mots-clés: nouvelles, réalisme, insomnie, crise, somatisation, aliénation, Etats-Unis

Keywords: short fiction, realism, insomnia, crisis, somatization, alienation, United States 